\title{
Waldegrave says White Paper will not seek radical changes
}

London. The forthcoming White Paper (policy document) on British science and technology is likely to be "evolutionary rather than revolutionary", William Waldegrave, the cabinet minister responsible for science, last week told a meeting at Imperial College, London, organized by Save British Science.

The White Paper is still more than two months away, and Waldegrave refused to describe it in detail. But he lifted the edge of the curtain sufficiently to suggest that he is unlikely to adopt some of the more radical proposals submitted to the Office of Science and Technology last autumn, for example those from the Advisory Council on Science and Technology (ACOST) for a clear split between 'curiosity-driven' and 'missionorientated' research councils.

While the ACOST report called for a sharper demarcation between the roles of government, the research councils and the scientific community, Waldegrave wants to ensure that all were pulling in the same direction. "We need somewhat more of a coherent national view about the broad direction of science and technology as they are relevant to this country, and a greater and more formalized exchange between players across the board", he said.

The principal actors in medical research, namely the research councils, charities and the health service, interact well, he said, adding that he "would like to see that more formally replicated in other areas". His words will reassure the Medical Research Council, which is concerned that implementation of the ACOST proposals could force it to hive off its research institutes through a process of "privatization".

Given the latest projections on public spending, it was no surprise that Waidegrave had little to offer those requesting a massive injection of new funds. Claiming that his hands are tied by the Treasury, Waldegrave said the real question was whether Britain was spending money in the right places.

A new report from Save British Science shows that Britain is continuing to fall behind its main economic competitors in terms of spending in research and development. But Waldegrave said he had "a great deal of scepticism about simplistic comparisons [of gross national products]". It was clear, he said, that economic performance is not automatically increased by spending more on science and technology. "If that were true, the states which make up the former Soviet Union would be in a strong position today", he said.

A consensus on the areas of science and technology on which the country should focus its resources would also provide a framework for the educational system. "We have to send signals to people in science at schools and institutions of higher education if they are going to respond in a way which is good over a period of time."

There was a broad hint in the minister's speech that the White Paper is likely to contain measures to encourage the private sector to invest more in research. Waldegrave admitted that it was not doing enough at present but that it has been successful in areas - for example the pharmaceutical industry - where there has been a heavy investment. "We have to consider whether there are governmental things we can do to help this", he said.

$\mathrm{He}$ also held out some words of comfort for universities who feared that the White Paper will encourage them to turn away from fundamental research. There is no simplistic view that applied research is good and basic research is bad, he said. What should matter for universities is first that the work is excellent and interesting and second that it supports their educational role.

David Dickson

\section{Cold Spring Harbour promotes Stillman}

Cold Spring Harbor, New York. Bruce Stillman has been named director of Cold Spring Harbor Laboratory, succeeding James Watson, who will become president on 1 January 1994 "There are many things to be done $\begin{array}{cl}\text { IMAGE } & \text { here, and one per- } \\ \text { UNAVAILABLE } & \text { son cannot do }\end{array}$ FOR them all", says Stillman about the COPYRIGHT dual positions. REASONS Stillman, 40, joined the laboratory in 1979 as a postdoctoral fellow and has been assistant director

Bruce Stillman for the past two years. An expert on DNA replication, he will remain an active scientist as well as managing the laboratory's science programme. Watson, who has been director for 25 years and who turns 65 this year, will coordinate policy in a position created this month by the board of trustees. He will also be on sabbatical next year as a visiting professor at the University of Oxford.

The laboratory has 220 scientists and an annual operating budget of \$33 million.

Jeffrey Mervis

\section{CHINA IN BRIEF}

Beijing. China is coping with a scientific 'talent fault' caused by the Cultural Revolution by promoting record numbers of scientists under the age of 50 at the nation's leading universities and by making research grants from an "outstanding young talent fund". Beijing University this year promoted 54 lecturers - 31 to full professor and 23 to associate professor - under the age of 50 , a record that university officials say is "an exception" to the normal age limits for professorships. Some two dozen are under the age of 35 , with the youngest, chemistry professor Lai Lu-Hua, only 29.

The rapid promotion of younger faculty can be disruptive in a country where seniority is still paramount. But it has become necessary given the fact that faculty must retire at the age of 65 and an increased emphasis on commercialization is drawing many younger professors into industry.

The National Natural Science Foundation received almost 200 applications for its first-ever round of young talent awards, which provide as much as 300,000 yuan (US $\$ 55,000$ ) over three years. Eleven of the 14 recipients have studied abroad, a fact that Chinese officials see as evidence of the value of international scientific exchanges.

Only 15 per cent of the more than 50,000 researchers at the various institutes operated by the Chinese Academy of Sciences will be allowed to continue with basic research in a sweeping reorganization of the scientific work force. Another 15 per cent will be given work collecting and analyzing data relating to natural resources and environmental management, while the rest - more than 30,000 researchers - will be left to find outside support for applied research that directly benefits the Chinese economy. The academy says that those remaining in basic research will receive preferential treatment and generous funding as part of an attempt to develop an elite corps of world-class scientists. Those going into applied research are expected to join such new creations as engineering centres, joint ventures and industrial conglomerates, aided by half a dozen shareholding companies being set up by the state.

China last week celebrated its first National Day for Science as part of the country's campaign to make scientific and technological research more marketorientated. A national fair in Beijing featured research institutions displaying their products to potential customers in an effort to increase the rate - now at 15 per cent - at which the country's current 20,000 research projects now result in commercial products. The date marks the fifteenth anniversity of a speech by senior leader Deng Xiao Ping that emphasizes the importance of science and technology to economic development. 